\title{
EFFECTS OF ENVIRONMENTAL TEMPERATURE UPON CAPILLARY RESISTANCE IN PATIENTS WITH RHEUMATOID ARTHRITIS AND OTHER INDIVIDUALS
}

\author{
BY \\ J. L. POTTER AND J. J. R. DUTHIE \\ Rheumatic Diseases Unit, Northern General Hospital, Edinburgh
}

In two previous surveys of capillary resistance (C.R.) it was found that the mean resistance in groups of patients with rheumatoid arthritis was significantly lower than in groups with other diseases (Potter and Wigzell, 1957). In these surveys the inter-subject variation of C.R. was substantial, even after allowance was made for the systematic influence of age, sex, and disease. The data consisted of the results of one test per individual and therefore provided no information on the nature of the residual variation. This presumably included genuine interand intra-subject variation, together with variation due to experimental error. As with other methods for measuring C.R., the negative pressure tests used in these surveys cannot be repeated in a given area of skin at intervals of less than 24 hours, hence strict replication is impossible, and the error of the test cannot be measured directly.

In a retrospective analysis of existing data it is permissible to deduct a proportion of the total variation which can be assigned to the systematic influence of any factor, such as correlation with the ages of the subjects tested, provided that there is a precedent or other independent evidence for the correlation.

With regard to the second of the foregoing surveys, analysis of the data revealed a statistically significant inverse relationship between the results of C.R. tests and environmental temperature, but only in the group of patients with rheumatoid arthritis. Since it lacked the support of independent evidence, this finding was omitted from the original report pending confirmation.

There is evidence that tests of capillary resistance may be a measure of some property of connective tissue (Potter and Wigzell, 1957), and it was concluded that the possible relationship between C.R. and environmental temperature merited further investigation. While it is a popular belief that weather has a determining influence upon rheumatic $\stackrel{N}{N}$ symptomatology, such experience is neither univer- $\vec{A}$ sally nor consistently described by those suffering from musculo-skeletal disorders.

In planning the experiments reported here, it was decided that a minimum of five C.R. tests at 1- or 2-day intervals would serve as a basis for exploring $\Phi$ the effects of environmental temperature in a suitable $\vec{\varphi}$ number of patients. It was further considered thgt $\stackrel{\sigma}{-}$ precise quantitation of a relationship between C. and environmental temperature should not expected, since both measurables were likely to have a large experimental error. However, it was believed that any real trend would be demonstrable by this approach, which has indeed confirmed that there is an inverse relationship between C.R. in patients with rheumatoid arthritis and environmental temperature.

\section{Material and Methods}

A total of 900 C.R. tests were performed in 72 subjects, including four normal individuals, 41 patients with rheumatoid arthritis, and 27 patients with other diseases (Table I).

TABLE I

COMPOSITION OF GROUPS INVESTIGATED

\begin{tabular}{|c|c|c|c|c|c|c|}
\hline \multirow{2}{*}{ Group (by diseases) } & \multicolumn{3}{|c|}{ Number Investigated } & \multicolumn{3}{|c|}{ Age (yrs) } \\
\hline & Male & Female & Total & Max. & Min. & Mean \\
\hline $\begin{array}{l}\text { Rheumatoid Arthritis } \\
\text { Other Diseases } \\
\text { Normal } \\
\text { Rheumatoid Arthritis } \\
\text { during Administra- } \\
\text { tion of Steroid* }\end{array}$ & $\begin{array}{r}24 \\
13 \\
3\end{array}$ & $\begin{array}{r}17 \\
14 \\
1\end{array}$ & $\begin{array}{r}41 \\
27 \\
4\end{array}$ & $\begin{array}{l}67 \\
76 \\
45\end{array}$ & $\begin{array}{l}17 \\
20 \\
28\end{array}$ & $\begin{array}{l}51 \\
43 \\
35 \\
\\
48\end{array}$ \\
\hline Total ... & 40 & 32 & 72 & & & \\
\hline
\end{tabular}

- Cortisone orally 50-100 mg. per 24 hrs, or Prednisolone orally 5-20 mg. per 24 hrs 
The diagnosis of rheumatoid arthritis was in accordance with the criteria for "definite R.A." proposed by the American Rheumatism Association (Ropes, Bennett, Cobb, Jacox, and Jessar, 1957). While under investigation, each patient was confined to bed within the ward for the whole or greater part of the day. The majority of tests were performed during the forenoon. Treatment of the patients with rheumatoid arthritis was maintained during the investigation. It consisted of supportive and corrective physical therapy, together with the administration of analgesics, mainly salicylates.

Additional C.R. tests were performed in 24 of the patients with rheumatoid arthritis during periods in which they received oral cortisone or prednisolone for therapeutic or investigative purposes. It has been shown that cortisone and ACTH have a profound effect upon C.R. in rheumatoid arthritis (Robson and Duthie, 1952) and, for this reason, the data obtained on C.R. in patients receiving steroid hormones were excluded from the general analysis of variance.

The atmospheric temperature was recorded after each C.R. test from a mercury thermometer placed near the subject. In some experiments these data were supplemented by continuous records of atmospheric temperature obtained with a thermograph situated near the patient or patients under observation. To test the possibility that C.R. might be influenced by other environmental factors indirectly measured by the atmospheric temperature in the ward, additional data were obtained from the records of a nearby meteorological station.

The negative pressure apparatus, consisting of a suction pump, reservoir, manometer, control valves, and a 23-mm. suction cup, has been described previously (Potter and Wigzell, 1957). In each test, the cup was used to transmit a series of negative pressures, of -50 , $-100,-150, \ldots \mathrm{mm}$. $\mathrm{Hg}$, all to the same area of skin. Each negative pressure was maintained for 30 seconds, and the petechiae, if any, were counted in the following interval of 30 seconds when the cup was lifted from the skin. The procedure was terminated when ten or more petechiae were produced within the skin under the cup.

The "critical petechial pressure" has been defined as the negative pressure producing only one petechia in a given area of skin exposed for a specified interval (Robson and Duthie, 1950). From extended observation it has become apparent that the numbers of petechiae increase in a logarithmic fashion in response to pressures more negative than the "critical pressure". In other words, there exists a close linear correlation between log. no. of petechiae and applied negative pressure in $\mathrm{mm}$. $\mathrm{Hg}$. On this basis it was possible to determine the regression equation most closely fitting the successive counts of petechiae in a C.R. test, and from this equation to estimate the negative pressure eliciting exactly ten petechiae. The result of each test was recorded as the figure so obtained, and provided a simple index of resistance which minimized the effect of random errors in the original petechial counts. In practice the index was read from a Table incorporating the appropriate function for three to five petechial counts at $50-\mathrm{mm}$. increments of negative pressure.

All tests were performed on the area of skin located by aligning the outer rim of the suction cup with the biceps tendon and with the lowermost crease at the elbow.

\section{Results}

As this investigation was designed to explore possible relationships between environmental temperature and capillary resistance, correlation between these two variables was estimated for each subject individually (Table II).

TABLE II

DISTRIBUTION OF POSITIVE AND NEGATIVE COEFFICIENTS OF CORRELATION OR OF REGRESSION OF C.R. ON ATMOSPHERIC TEMPERATURE

\begin{tabular}{|c|c|c|c|c|}
\hline \multirow[t]{2}{*}{ Group (by disease) } & \multirow[t]{2}{*}{ Sex } & \multicolumn{2}{|c|}{$\begin{array}{l}\text { No. of Individuals } \\
\text { in whom Coeffici- } \\
\text { ents were }\end{array}$} & \multirow[t]{2}{*}{ Total } \\
\hline & & Positive & Negative & \\
\hline \multirow{2}{*}{$\begin{array}{c}\text { Patients with Rheumatoid } \\
\text { Arthritis (untreated) }\end{array}$} & \begin{tabular}{ll|} 
Male & $\ldots$ \\
Female &..
\end{tabular} & $\begin{array}{l}3 \\
4\end{array}$ & $\begin{array}{l}21 \\
13\end{array}$ & $\begin{array}{l}24 \\
17\end{array}$ \\
\hline & Total .. & 7 & 34 & 41 \\
\hline \multirow{2}{*}{$\begin{array}{l}\text { Patients with Other Diseases } \\
\text { and Normal Subjects }\end{array}$} & \begin{tabular}{ll|} 
Male & Female \\
Fem
\end{tabular} & 99 & $\begin{array}{l}7 \\
4 \\
\end{array}$ & $\begin{array}{l}16 \\
15 \\
\end{array}$ \\
\hline & Total . . & 20 & 11 & 31 \\
\hline \multirow{2}{*}{$\begin{array}{l}\text { Patients with Rheumatold } \\
\text { Arthritis (on steroids) }\end{array}$} & \begin{tabular}{ll|} 
Male & $\ldots$ \\
Female & $\ldots$
\end{tabular} & $\begin{array}{l}9 \\
7\end{array}$ & $\begin{array}{l}6 \\
2\end{array}$ & $\begin{array}{r}15 \\
9\end{array}$ \\
\hline & Total .. & 16 & 8 & 24 \\
\hline
\end{tabular}

For distribution of positive and negative coefficients between patients with rheumatoid arthritis and unaffected patients, $X^{2}=15$; $P<0.01$.

For distribution of positive and negative coefficients in patients with rheumatoid arthritis (untreated) and in patients with rheumatoid with rheumatoid arthritis (untreated) and in
arthritis on steroids, $X^{2}=15 ; P<0.01$.

Although only 21 per cent. of the coefficients are significant at a probability of 1 in 20 , the distribution of positive and negative coefficients is significantly non-homogeneous. *

On this basis, the estimated error deviation of capillary resistance was $46 \mathrm{~mm}$. $\mathrm{Hg}$ (Table III, overleaf).

This value is proportionately little greater than the error of many other biological measurables. The significant differences in C.R. between individuals within each group support the view that the observed variation in resistance occurs around a level characteristic for each individual.

Six patients with rheumatoid arthritis were

* If no real correlation existed, the estimated coefficients should be distributed symmetrically around zero, and in any large sample the number of "significant" coefficients (at a probability of 1 in 20) number of "significant" coeffich
should approach 5 per cent. 
TABLE III

ANALYSIS OF VARIANCE IN 900 C.R. TESTS IN 72 INDIVIDUALS

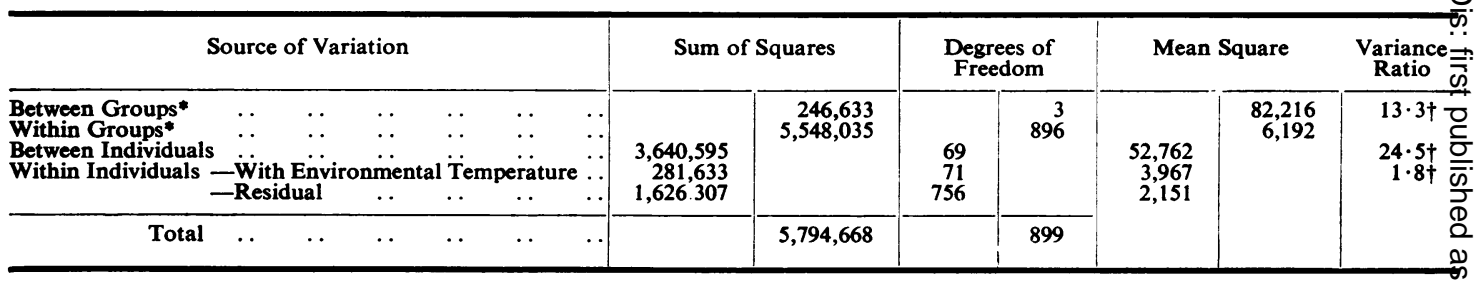

* Four Groups: Patients with Rheumatoid Arthritis - Male -Female

exposed to large fluctuations of environmental temperature over a period of one week, during which the C.R. was measured twice daily on alternate arms. In these circumstances it was readily apparent that resistance varied inversely with atmospheric temperature (Figure).
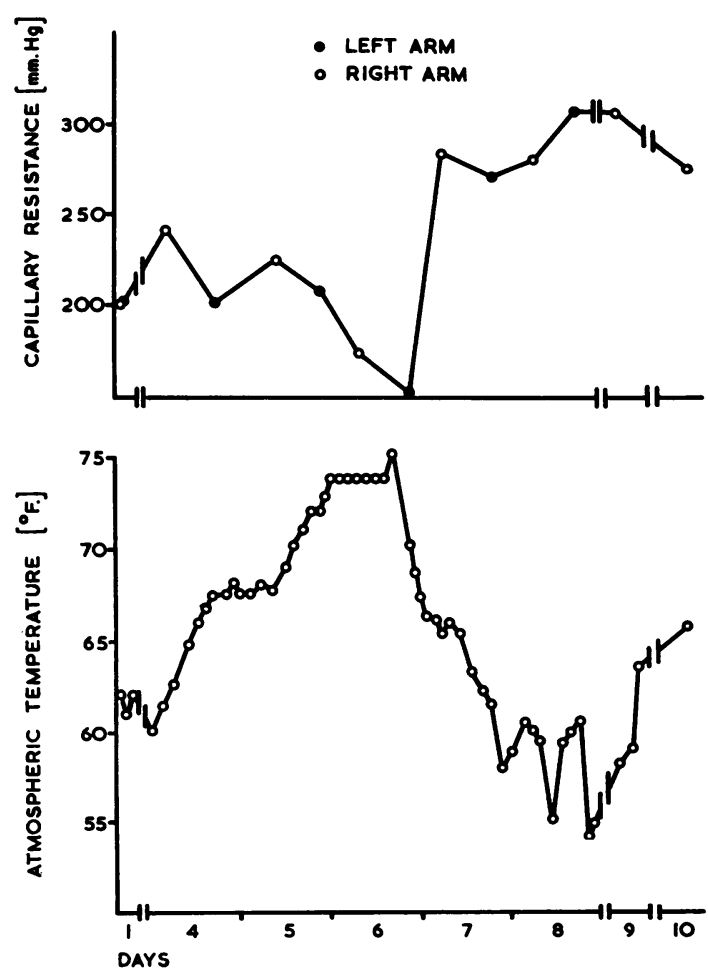

Figure.-Effect of environmental temperature on capillary resistance in a patient with rheumatoid arthritis. Resistance was measured twice daily in a man aged 29 years confined to a room where the atmospheric temperature was made to vary over the range shown in the lower trace.
Other Subjects - Male

+ Significant at the 1 per cent. leve $\overleftarrow{5}$

However, it was evident that the resistance might be influenced more by the direction of temperatures change than by the actual level of temperature; i.e. in response to a rise in temperature the $C . R_{\vec{A}}$ fell initially, but subsequently increased again if the temperature was maintained at the new level. $\frac{\text { O }}{3}$

From all of the data it has been estimated that $\vec{z}$ in patients with rheumatoid arthritis, the C.RE tended to vary inversely with environmental tem $\vec{D}$ perature. (On average, resistance fell by $4 \mathrm{~mm}$. $\mathrm{Hg}$ with a temperature increase of $1^{\circ} \mathrm{F}$., and vice versg. 尺 $^{\circ}$ In other subjects the resistance tended to vary directly with environmental temperature. (8n? average, resistance increased by $2 \mathrm{~mm}$. $\mathrm{Hg}$ with a temperature increase of $1^{\circ} \mathrm{F}$., and vice versa. The data on C.R. in patients receiving cortisone of prednisolone were analysed separately and the results are outlined in Table II. In patients with rheuma toid arthritis a negative correlation between C.R and temperature was no longer apparent during steroid therapy. Instead, the resistance tended to vary directly with the temperature, but the average correlation was not significant. This effect of steroids will be discussed.

Appropriate tests showed some correlation between the temperature of the atmosphere within the wards (measured with a mercury thermometer or thermograph) and the external temperature recorded at the meteorological station. This maso be a measure of the efficiency of the central heating system and probably also reflects a traditionabs regard for the therapeutic value of fresh air, howeven cold. The pattern of correlation between C.RN and temperature was essentially the same for alf sources of data on the latter; there was no correlation between capillary resistance and barometrice pressure.

\section{Discussion}

From the foregoing data it has been inferred thati in 72 subjects a significant proportion of the vari $\frac{\text { }}{\mathrm{D}}$ 
ability of capillary resistance was a consequence of fluctuation in the atmospheric environmental temperature. In this group, furthermore, the patients with rheumatoid arthritis differed from the other individuals in the pattern of the C.R. response to a change of environmental temperature. The biological mechanisms involved in the response are as yet unidentified, but the results indicate that experimental error alone does not explain the rise or fall of resistance occurring in an individual within the 24-hour period between successive determinations.

The variability of C.R. thus demonstrable implies a similar lability in the tensile strength of tissues supporting the small cutaneous blood vessels. In terms of histology, the perivascular "sheath" of connective tissue shows little or no variation except when it has been disorganized, for example, by a relatively gross focal inflammatory lesion, and for this reason might be regarded as having little or no dynamic potential. In contrast, the cutaneous vessels per se are highly responsive to neurohumoural stimuli. While it might be reasonable to assume that the day-to-day variability of C.R. is a manifestation of changes in vasomotor activity, there is impressive evidence to the contrary. In a series of careful experiments performed on normal subjects, Wigzell (1958) found that capillary resistance was essentially uninfluenced by reflexlyinduced vasodilatation and constriction, despite a well-marked vasomotor response throughout the area of skin where the C.R. was determined. From evidence previously reviewed, moreover, it was concluded that capillary resistance is a measure of some property of the connective tissue ensheathing small cutaneous vessels and particularly the collecting venules (Peck, Rosenthal, and Erf, 1937; Zweifach, 1955; Potter and Wigzell, 1957; Wigzell, 1958).

The perivascular sheath can be considered to include two major components forming a network of collagen fibres in a matrix of amorphous ground substance. Of the two components, the second would seem to have the greater potential for undergoing rapid changes of state. It is conceivable that a change in the properties of ground substance could modify the tensile strength of the collagen network, and yet escape detection by existing histological techniques. Analogous interdependence of structural components is evident in other tissues such as bone and, probably, articular cartilage (McElligott and Potter, 1960).

In the course of the investigation it was observed that administration of corticosteroid hormones to patients with rheumatoid arthritis modified the effect upon the C.R. of a change in the environmental temperature. During steroid administration correlation between resistance and temperature was in general less negative than in untreated patients and thus tended to approach the positive direct correlation which was characteristic both of the group of patients with diseases other than rheumatoid arthritis and of the group of normal individuals. This effect need not signify that steroid administration corrected any defect fundamental to the "abnormal" pattern of C.R. response in patients with rheumatoid arthritis, but in the context of this discussion it is relevant to postulate that the hormonal effect was mediated by changes occurring primarily in the perivascular connective tissue, or else in the mechanism linking this tissue with the environment. While the latter possibility is entirely speculative, there is some evidence that cortisone has a local effect upon the amorphous component of dermal connective tissue, since restoration of the "dermal barrier" after injection of hyaluronidase was accelerated in patients with Still's disease during treatment with cortisone (Bywaters, Holborow, and Keech, 1951).

At present little is known about the true nature of the properties measured indirectly by negative pressure C.R. tests. Hence it is necessary to defer complete evaluation of the biological significance of the effects of environmental temperature described in this report. That individuals differ in their response to environmental temperature may be of practical importance in surveys to determine C.R. in health and disease. Such data, reported by a number of different observers, have appeared in some instances to be mutually contradictory (Hare and Miller, 1951). These anomalies might well have arisen from the unrecognized influence of the subjects' environmental temperature in the interval before a C.R. test performed under standard environmental circumstances.

Finally, the present findings may be regarded as objective evidence of a relationship between "rheumatism" and "weather". Obscure and complex as it appears to be, such a relationship has escaped demonstration in any previous multifactorial exploration.

\section{Summary}

(1) Capillary resistance (C.R.) was measured repeatedly in individual subjects, including 41 patients with rheumatoid arthritis and 27 with other diseases.

(2) Analysis of the results revealed a negative correlation between C.R. and environmental temperature in the group of patients with rheumatoid 
arthritis. In contrast, correlation between the two variables was positive in the remaining group of subjects.

(3) During administration of corticosteroid hormones to patients with rheumatoid arthritis, the correlation between C.R. and temperature tended to become more positive, i.e. less "abnormal".

(4) These findings are discussed in terms of their implications in relation to the structure and function of the tissues supporting the small cutaneous blood vessels.

During the period when this work was done, the Rheumatic Unit was in receipt of grants from the Nuffield Foundation, the Medical Research Council, and Boots Pure Drug Company Limited. During the period when the material was prepared for publication one author (J.L.P.) was supported by a grant from the John Polachek Foundation for Medical Research, New York, N.Y., and secretarial assistance was provided by a grant from the Empire Rheumatism Council.

\section{REFERENCES}

Bywaters, E. G. L., Holborow, E. J., and Keech, M. K. (1951). Brit. med. J., 2, 1178.

Hare, F. W., and Miller, A. J. (1951). A.M.A. Arch. Derm. Syph., 64, 449.

McElligott, T. F., and Potter, J. L. (1960). J. exp. Med., $112,743$.

Peck, S. M., Rosenthal, N., and Erf, L. (1937). Arch. Derm. Syph. (Chicago), 35, 831.

Potter, J. L., and Wigzell, F. W. (1957). Ann. rheum. Dis., 16, 357.

Robson, H. N., and Duthie, J. J. R. (1950). Brit. med. J., $2,971$. (1952). Ibid., 1, 994.

Ropes, M. W., Bennett, G. A., Cobb, S., Jacox, R., and Jessar, R. A. (1957). J. chron. Dis., 5, 630.

Wigzell, F. W. (1958). Thesis for the Degree of Doctor of Medicine of the University of St. Andrews.
Zweifach, B. W. (1955). Ann. N.Y. Acad. Sci., 61, Art. 3, p. 670.

Effet de la température ambiante sur la résistance capillaire $\frac{}{\omega}$ chez des malades atteints d'arthrite rhumatismale et chez d'autres sujets

\section{RÉSUMÉ}

(1) On mesura à plusieurs reprises la résistance capillaire chez un nombre de sujets, y compris 41 malades atteints d'arthrite rhumatismale et 27 sujets atteints d'autres maladies.

(2) L'analyse des résultats montre une corrélation négative entre la résistance capillaire et la température ${ }^{\infty}$ ambiante dans le groupe des malades atteints d'arthrite $\vec{\circ}$ rhumatismale. Par contre, la corrélation entre les deux variables fut positive chez tous les autres.

(3) Pendant l'administration d'hormones cortico- $\omega$ stéroìdes aux malades atteints d'arthrite rhumatismale, la corrélation entre la résistance capillaire et la température 0 ambiante tendait à devenir positive, c'est-à-dire, moins î "anormale".

(4) On discute ces résultats du point de vue de leurs? implications en ce qui concerne la structure et la fonction $\vec{P}$ des tissus qui supportent les petits vaisseaux sanguins de la peau.

Efecto de la temperatura ambiente sobre la resistencia capilar en enfermos con artritis reumatoide $y$ en otros sujetos

SUMARIO

(1) Se midió repetidamente la resistencia capilar \& un grupo de sujetos que comprendía también 41 enfermas con artritis reumatoide y 27 con otras enfermedades.

(2) El análisis de los resultados demuestra una cof relación negativa entre la resistencia capilar y la teri-peratura ambiente en el grupo de enfermos con artritis reumatoide. En contraste, la correlación entre las dos variables fué positiva en el resto de los sujetos.

(3) Durante la administración de hormonas cortico- $\overrightarrow{\vec{B}}$ steroides a enfermos con artritis reumatoide la cor- 3 relación entre la resistencia capilar y la temperatura ambiente tendía a ser positiva, esto es, menos "anormal".

(4) Se discuten tales hallazgos desde el punto de vista de sus implicaciones en relación con la estructura y función de los tejidos que contienen los pequeños vasos $\overline{0}$ cutáneos. 